\title{
Idiopathic chronic cough: a real disease or a failure of diagnosis?
} LPA McGarvey*

\author{
Address: Department of Medicine, The Queen's University of Belfast, Grosvenor Road, Belfast BT126BJ, N Ireland, UK \\ Email: LPA McGarvey* - l.mcgarvey@qub.ac.uk \\ * Corresponding author
}

Published: 23 September 2005

Cough 2005, 1:9 doi:10.1186/1745-9974-1-9

This article is available from: http://www.coughjournal.com/content/I/I/9

() 2005 McGarvey; licensee BioMed Central Ltd.

This is an Open Access article distributed under the terms of the Creative Commons Attribution License (http://creativecommons.org/licenses/by/2.0), which permits unrestricted use, distribution, and reproduction in any medium, provided the original work is properly cited.
Received: 24 March 2005

Accepted: 23 September 2005

\begin{abstract}
Despite extensive diagnostic evaluation and numerous treatment trials, a number of patients remain troubled by a chronic and uncontrollable cough. Eosinophilic bronchitis, atopic cough and non-acid reflux have been recently added to the diagnostic spectrum for chronic cough. In some cases, failure to consider these conditions may explain treatment failure. However, a subset of patients with persisting symptoms may be regarded as having an idiopathic cough. These individuals are most commonly female, of postmenopausal age and frequently report viral upper respiratory tract infections as an initiating event. This paper seeks to explore the validity of idiopathic cough as a distinct clinical entity.
\end{abstract}

\section{Introduction}

Despite considerable advance in the understanding of cough, the effective management of patients with a chronic cough can be difficult. For the patient, a cough which persists can be associated with considerable distress and impaired quality of life [1]. For the physician, failure to obtain a treatment response may lead to the mistaken belief that the cough is functional or psychogenic. There are a number of reasons why the cough may be difficult to treat. In some cases it may reflect an inadequate approach to diagnostic evaluation and failure to appreciate both pulmonary and extra pulmonary causes for chronic cough $[2,3]$. In other cases, trials of therapy may be of inadequate dose and of insufficient duration. However, an alternative explanation is that a distinct diagnostic entity exists, namely idiopathic cough [4]. If this is the case then almost nothing is known about the underlying pathophysiological processes responsible for this condition and at present there are no effective treatment options. This article seeks to examine the evidence for idiopathic cough as either a distinct diagnosis or simply the result of incomplete evaluation and inadequate courses of therapy.

\section{Diagnostic protocols for chronic cough}

The term 'idiopathic' comes from the Greek word idiopatheia and is defined in the Oxford English Dictionary as a 'disease not preceded or occasioned by another, or by any known cause' [5]. In the original description of cough evaluation and management by Irwin and colleagues, idiopathic cough was not described and indeed treatment failure was extremely rare [6]. Using a stepwise approach known as the anatomic diagnostic protocol, Irwin and colleagues reported that a cause for cough could be determined successfully in up to $98 \%$ of cases and was due to either cough variant asthma (CVA), rhinosinusitis associated with postnasal drip syndrome (PNDS) or gastrooesophageal reflux disease (GORD) [6]. The subsequent experience from this group $[7,8]$ and a number of others in hospital-based settings $[9,10]$ has remained the same and the diagnostic protocol has been recommended by 
the American College of Chest Physicians in their clinical guidelines for the management of cough [11].

Although the systematic evaluation of both extrapulmonary and pulmonary causes for cough is widely held to be effective, doubt has been cast on the perception that the diagnostic triad of CVA, PNDS and GORD accounts for the almost all causes of chronic cough $[12,13]$. Despite adopting a comprehensive evaluation of patients referred with cough, many groups have reported diagnostic and treatment failure in anything from $12-42 \%$ of patients [14-16]. For some, this represents a population with idiopathic cough [16] but others suggest it reflects failed management [17]. Specifically, the failure to prescribe sedating antihistamines for postnasal drip syndromes [17] and the inadequate treatment of gastro-oesophageal reflux disease have been highlighted [18].

There are a number of possible explanations for the impressive treatment response described by Irwin and others. Firstly, it is probable that the original referral populations included patients with cough following a viral upper respiratory infection. It is now recognised that cough following an upper respiratory tract infection may persist beyond three weeks and only resolve spontaneously some weeks or months later. Therefore some of the 'treatment success' may merely have reflected the natural resolution of a prolonged post-viral cough. Secondly, many patients were prescribed older generation antihistamines, which have an imprecise pharmacological action but presumably exert most of their antitussive effect by crossing the blood-brain barrier and acting directly on the cough control centre within the brain. Crucially, response to such therapy tells us little about the aetiology of the cough. Finally, these original studies reported on shortterm treatment outcomes and provided little information on the long-term treatment response. Initial treatment benefit may well diminish over time and the timing of patient follow-up may explain some of the variance in outcome described by different centres [19].

\section{Failure to adequately treat cough}

Current guidelines have recommended a combination of diagnostic testing and empirical trials in the management chronic cough [20]. Some authors have reported that the characteristics of a cough confer little diagnostic information [21] but in practice, prominent symptoms of an upper airway disorder or indigestion should prompt a treatment trial of anti-rhinitic therapy or anti-reflux therapy [20]. The question of how much and for how long of a specific treatment has yet to be unequivocally answered. This point is perhaps best illustrated in the management of GORD associated cough. Although lacking a strong evidence base, it may be necessary to embark on intensive courses of anti-reflux therapy, because in contrast to the symptoms of heartburn, which usually resolve after a few days treatment, improvement in cough seems to take much longer $[18,22]$. In one study, mean duration to treatment success was 179 days [18]. As a consequence, failure to comply with prolonged therapy and lifestyle changes may result in relapse and explain poor treatment success even in patients with a high suspicion of GORD associated cough [19].

Alternatively, some individuals on relatively high doses of acid suppression may exhibit relative proton pump therapy resistance. This is particularly the case with attempts to suppress proximal and laryngophayngeal reflux where despite single and higher dose treatment regimes, $44 \%$ of patients demonstrated abnormal levels of acid exposure on simultaneous oesophagel and laryngeal $\mathrm{pH}$ testing [23]. Finally, a minority of patients who fail adequate courses of acid suppressive therapy may ultimately require anti-reflux surgery [24]. This final observation has contributed to the growing appreciation that acid may not be the sole aggravating factor in gastric refluxate. Until recently, this concept of 'non-acid reflux' as a cause for cough had been infrequently considered. It will be discussed together with a number of other 'new causes for cough' in the subsequent section of this review.

\section{New causes for cough}

Given the extent of associated literature, it is barely conceivable that any respiratory physician is unaware of the most common associations with chronic cough, namely asthma, GORD and rhinosinusitis, more recently termed upper airway cough syndrome. In the last decade, a series of important observations have led to the appreciation of new diagnostic possibilities. Most importantly, the application of induced sputum in the evaluation of cough has led to the identification of eosinophilic airway syndromes [25]. These conditions are characterized by the presence of eosinophilic airway inflammation but crucially the absence of the airway dysfunction (airflow variability or bronchial hyperreactivity) normally attributed to asthma. The best-described condition is eosinophilic bronchitis, which may account for up to $15 \%$ of patients referred to hospital with chronic cough [26]. It frequently responds to inhaled corticosteroids, and as these are often prescribed empirically in the community the exact prevalence of this condition is unknown. More recently, a number of Japanese groups have described a syndrome of "Atopic Cough" [27]. These patients are atopic, have an isolated bronchodilator resistant cough and an eosinophilic tracheobronchitis. Like eosinophilic bronchitis, there is no evidence of airway hyperreactivity but in contrast, the cough does not respond to inhaled corticosteroids. Without adequate attention to the inflammatory characteristics of the airway, and reluctance to prescribe inhaled steroids to patients with normal airway function then either of 
these syndromes may be incorrectly labeled as having an idiopathic cough.

The concept of 'Non-acid reflux' has recently gained attention. Irwin and colleagues [24] reported on a group of 8 patients that had persistent cough despite total or near total acid suppression utilizing proton pump inhibitors, prokinetic agents and antireflux diet (omeprazole 20-80 mg p.o. daily and cisapride $40-80 \mathrm{mg}$ p.o. daily). These 8 patients had 24 hour ambulatory oesophageal $\mathrm{pH}$ monitoring while on medical therapy, and in all patients the \% of 24 hours spent at $\mathrm{pH}<4.0$ was zero or near zero. Despite this, all 8 patients underwent antireflux surgery with marked reduction in cough scores after surgery, which were maintained after 12 months of follow up. This study suggests antireflux surgery may improve cough that is resistant to medical therapy, and that the improvement is sustained. Acid reflux disease in patients with cough and GORD may be a misnomer since non-acid reflux may be responsible for cough in some patients (volume reflux with gastric enzymes, bile salts etc.) [28]. Thus failure to respond to antireflux therapy may not indicate an idiopathic chronic cough.

Finally an association between cough, GORD and a familial sensory neuropathy has recently been reported [29]. The locus for the particular gene appears to be located on chromosone 3 . In a series of personal communications with other cough specialists, it would appear similar associations have been encountered suggesting such clinical features may represent a new cough syndrome.

The common and less common associations with cough must be rigorously excluded before a diagnosis of idiopathic cough can be assigned. None-the-less, this author firmly believes such a condition exists and it will be addressed in some detail in the following section.

\section{Idiopathic cough as a distinct clinical entity}

The accumulation of experience and information regarding idiopathic cough suggests a fairly well defined population of patients. The over-representation of women in the specialist cough clinic referral population is widely acknowledged, and the preponderance of females among idiopathic coughers is particularly striking. Some centers have reported female prevalence rates of more than $80 \%$ [14-16,30-33] (See table 1). Gender differences in healthrelated quality of life and as a consequence differences in health seeking behaviour is one explanation [34] but others have suggested a distinct clinical phenotype [4]. Typically the female patients are of peri- or post menopausal age, report a preceding upper respiratory tract infection (URTI) and have a heightened cough reflex to tussive stimuli [16]. These observations raise the possibility that sex hormones and viral URTIs in some way contribute to the development of an idiopathic cough in susceptible individuals.

\section{Possible mechanisms for idiopathic cough}

The human cough reflex consists of an afferent arm comprising cough receptors, afferent pathways, central processing and an efferent pathway. The cough reflex can be modified at any point along this reflex and unraveling the mechanisms responsible is key to a more complete understanding of cough pathophysiology and its successful treatment. Afferent sensory nerves are not static entities and the term 'plasticity' has been used to describe changes in function contributing to the sensitization that occurs in response to various stimuli, in particular those associated with airway inflammatory processes [35]. Although viral infections are a major cause of cough and appear to be frequently reported in patients with idiopathic cough, little is known regarding the effects of viruses on cough sensitivity. Following respiratory syncytial virus infection in rats, tachykinin content within the lung is increased [36] along with an upregulation in the substance P receptor, neurokinin (NK) 1 [37]. These changes appear to persist for some time after the virus is cleared. In guinea pigs, inoculation with the Sendai virus has been associated with a qualitative change in airway sensory nerves whereby nonnociceptive neurons express tachykinins [38]. This 'phenotypic switch' is one plausible mechanism whereby viral infection causes increased tachykinergic content in airway nerves which possibly contribute to persistent reflex hypersensitivity and cough. It is unknown if such processes occur in man, but abnormal intraepithelial nerves containing increased neuropeptide content have been reported in bronchial biopsies from patients with idiopathic cough [39].

Only a few studies have specifically commented on findings in the airways of patients with idiopathic cough. Birring et al. observed a mild chronic lymphocytic airway inflammation in a predominately female population of idiopathic coughers and highlighted the striking association with organ specific autoimmune disease in particular hypothyroidism [40]. They suggested that the presence of increased lymphocytes within the airway reflected either an aberrant homing of lymphocytes from the primary site of autoimmune inflammation to the lung or a distinct autoimmune process within the lungs [40]. A more recent study has confirmed the dominance of lymphocytes in the airways of females with idiopathic cough. In this study, significantly elevated numbers of activated CD4+ lymphocytes were noted in bronchoalveolar lavage fluid from menopausal women with isolated dry cough compared to matched controls. This group hypothesized that menopausal effects on lymphocyte activation within the airway may lead to disordered responses to airway insults such as infection [41]. 
Table I: Characteristics of idiopathic cough patients attending specialist cough clinics

\begin{tabular}{llll}
\hline & Number (\% female) & Mean age (SD) (years) & $\begin{array}{l}\text { Median cough duration (range) } \\
\text { (months) }\end{array}$ \\
\hline O'Connell F et al [14] & $16(81 \%)$ & $5 I(31-70)^{*}$ & $72(12-240)$ \\
McGarvey L et al [15] & $8(75 \%)$ & $46(8)$ & $19(6-36)$ \\
Forsythe P et al [30] & $6(66 \%)$ & $47(13)$ & $72(2-240)$ \\
Jatakanon A et al [3I] & $10(50 \%)$ & $60(4)$ & $60(18)^{\wedge}$ \\
Birring SS et al [32] & $25(72 \%)$ & $55(3)$ & $12(7-360)$ \\
Chaudhuri R et al [33] & $6(60 \%)$ & $58(9)$ & $14(19)^{\wedge}$ \\
Haque R et al [16] & $31(76 \%)$ & $57(32-81)^{*}$ & $72(8-324)^{*}$ \\
\hline
\end{tabular}

*Data given as median (range), ^Data given as mean (SD)

Gender and sex hormones may have important effects on neuro-immune events within the airway. A number of studies have demonstrated a heightened cough reflex sensitivity in females compared to males both in healthy individuals $[42,43]$ and cough subjects [44]. This gender difference has not been observed in children, raising the possibility that sex hormones may influence the reflex [45]. Women of post-menopausal age appear to have a heightened cough reflex although this has not been consistently demonstrated [46]. None-the-less, oestrogen levels begin to decrease around the time of the menopause, which may exert an effect on cough reflex sensitivity. Danazol, a synthetic androgen that decreases oestrogen levels, has been shown to inhibit the upregulation of the cough reflex observed in female guinea pigs following treatment with an ACE-inhibitor [47].

\section{Conclusion}

Although inadequate management will continue to explain a significant number of patients with a chronic and uncontrollable cough, an attempt has been made in this article to highlight idiopathic cough as a distinct clinical entity. Although without firm evidence, idiopathic cough may arise as a consequence of the persisting effects of viral infection or other noxious aggravants in susceptible individuals. The excess of middle-aged females with idiopathic cough raises the possibility of some sex hormonal influence. Precision in this area will be greatly hampered unless further research is undertaken.

\section{References}

I. French CL, Irwin RS, Curley FJ, Krikorian CJ: Impact of chronic cough on quality of life. Arch Intern Med I998, I58:|657-|66I.

2. Al-Mobeireek AF, Al-Sarhani A, Al-Amri S, Bamgboye E, Ahmed S: Chronic cough at a non-teaching hospital: Are extrapulmonary causes overlooked? Respirology 2002, 7:|4|-| 46.

3. McGarvey LPA, Heaney LG, MacMahon J: A retrospective survey of diagnosis and management of patients presenting with chronic cough to a general chest clinic. Int J Clin Pract 1997, 52:158-161.

4. McGarvey LPA, Ing AJ: Idiopathic cough, prevalence and underlying mechanisms. Pulm Pharmacol Ther 2004, 17:435-439.

5. The Oxford English Dictionary 2nd edition. New York: Oxford University Press.
6. Irwin RS, Corrao WM, Pratter MR: Chronic persistent cough in the adult: the spectrum and frequency of cases and successful outcome of specific therapy. Am Rev Respir Dis 198I, I 23:4|4-4|7.

7. Irwin RS, Curley FJ, French CL: Chronic cough: the spectrum and frequency of causes, key components of the diagnostic evaluation and outcome of specific therapy. Am Rev Resp Dis 1990, | 41:640-647.

8. Smyrnios NA, Irwin RS, Curley FJ: Chronic cough with a history of excessive sputum production: The spectrum and frequency of causes key components of the diagnostic evaluation, and outcome of specific therapy:- Chest 1995, 108:991-997.

9. Pratter MR, Bartter T, Akers S, Dubois I: An algorithmic approach to chronic cough. Ann Intern Med 1993, I 19:977-83.

10. Palombini BC, Villanova CA, Araujo E, Gastal OL, Alt DC, Stolz DP, Palombini CO: A pathogenic triad in chronic cough: asthma, postnasal drip syndrome and gastrooesophageal reflux disease. Chest 1999, I 16:279-8.

II. Irwin RS, Boulet LP, Cloutier MM, Fuller R, Gold PM, Hoffstein V, Ing AJ, McCool FD, O'Byrne P, Poe PH, Prakash UB, Pratter MR, Rubin $B K$ : Managing cough as a defence mechanism and as a symptom. A consensus panel report of the American College of Chest Physicians. Chest 1998, II 4:I33S-18IS.

12. Poe HR, Harder RV, Israel RH: Chronic persistent cough: experience in diagnosis and outcome using an anatomic diagnostic protocol. Chest 1989, 95:723-27.

13. Morice AH, Kastelik JA: Cough. I: Chronic cough in adults. Tho$\operatorname{rax} 2003, \mathbf{5 8}(10): 901-7$.

14. O'Connell F, Thomas VE, Pride NB, Fuller RW: Cough sensitivity to inhaled capsaicin decreases with successful treatment of chronic cough. Am J Respir Crit Care Med 1993, 150:374-80.

15. McGarvey LPA, Heaney LG, Lawson JT, Johnston BT, Scally CM, Ennis $M$, Shepherd DRT, MacMahon J: Evaluation and outcome of patients with chronic non-productive cough using a comprehensive diagnostic protocol. Thorax 1998, 53:738-743.

16. Haque RA, Usmani OS, Barnes PJ: Chronic Idiopathic cough: a discrete clinical entity? Chest 2005, 127:1710-17/3.

17. Irwin RS, Madison JM: Diagnosis and treatment of chronic cough due to gastro-esophageal reflux disease and postnasal drip syndrome. Pulm Pharmacol Ther 2002, 15:293-4.

18. Irwin RS, Madison JM: Anatomical diagnostic protocol in evaluating chronic cough with specific reference to gastrooesophageal reflux disease. Am J Med 2000, 108:126S-I30S.

19. Patterson RN, Johnston BT, MacMahon J, Heaney LG, McGarvey LPA: Oesophageal pH monitoring is of limited value in the diagnosis of 'reflux-cough'. Eur Respir J 2004, 24(5):724-7.

20. Morice AH, Fontana GA, Sovijarvi ARA, Pistolesi M, Chung KF, Widdicombe J, ERS Task Force, et al.: The diagnosis and management of cough. Eur Respir J 2004, 24:48I-492.

21. Mello CJ, Irwin RS, Curley FJ: The predictive values of the character, timing and complications of chronic cough in diagnosing its cause. Arch Int Med 1993, I 19:997-983.

22. Benini L, Ferrari M, Sembenini C, Olivieri M, Micciolo R, Zuccali V, Bulighin GM, Fiorino F, Ederle A, Cascio VL, Vantini I: Cough 
threshold in reflux oesophagitis: influence of acid and of laryngeal and oesophageal damage. Gut 2000, 46:762-7.

23. Amin MR, Postma GN, Johnston P, Digges N, Koufman JA: Proton pump inhibitor resistance in the treatment of laryngopharyngeal reflux. Otolaryngol Head Neck Surg 200 I, 1 25:374-8.

24. Irwin RS, Zawacki JK, Wilson MM, French CT, Callery MP: Chronic cough due to gastro-oesophageal reflux disease: Failure to resolve despite total/near total elimination of oesophageal acid. Chest 2002, I 2 I: I |32-I | 40.

25. Gibson PG, Dolovich J, Denburg J, Ramsdale EH, Hargreave FE: Chronic cough: eosinophilic bronchitis without asthma. Lancet 1989, I(9287): | 346-8.

26. Brightling C, Ward R, Goh KL, Wardlaw AJ, Pavord ID: Eosinophilic bronchitis is an important cause of chronic cough. Am J Respir Crit Care Med 1999, 160:406-10.

27. Fujimura M, Ogawa H, Nishizawa Y, Nishi K: Comparison of atopic cough with cough variant asthma: Is atopic cough a precursor of asthma? Thorax 2003, 58:14-18.

28. Sifrim D, Dupont L, Blondeau K, Zhang X, Tack J, Janssens J: Weakly acidic reflux in patients with chronic unexplained cough during 24 hour pressure, $\mathrm{pH}$, and impedance monitoring. Gut 2005, 54(4):449-54.

29. Kok C, Kennerson ML, Spring PJ, Ing AJ, Pollard JD, Nicholson GA: A locus for hereditary sensory neuropathy with cough and gastroesophageal reflux on chromosone 3p22-p24. Am J Hum Genet 2003, 73:632-7.

30. Forsythe P, McGarvey L, Heaney LG, MacMahon J, Ennis M: Sensory neuropeptides induce histamine release from bronchoalveolar lavage cells in both non asthmatic coughers and cough variant asthmatics. Clin Exper Allergy 2000, 30:225-32.

31. Jatakanon A, Lalloo UG, Lim S, Chung KF, Barnes PJ: Increased neutrophils and cytokines, TNF-alpha and IL-8, in induced sputum of non-asthmatic patients with chronic dry cough. Thorax 1999, 54:234-7.

32. Birring SS, Murphy AC, Scullion JE, Brightling CE, Browning M, Pavord ID: Idiopathic chronic cough and organ specific autoimmune diseases: a case control study. Respir Med 2004, 98(3):242-6.

33. Chaudhuri R, McMahon AD, Thomson LJ, MacLeod KJ, McSharry CP, Livingston E, McKay A, Thomson NC: Effect of inhaled corticosteroids on symptom severity and sputum mediator levels in chronic persistent cough. J Allergy Clin Immunol 2004, I 13:1063-70.

34. French $\mathrm{CT}$, Fletcher KE, Irwin RS: Gender differences in healthrelated quality of life in patients complaining of chronic cough. Chest 2004, I 25:482-8.

35. Carr MJ: Plasticity of vagal afferent fibres mediating cough. Pulm Pharmacol Ther 2004, 17:447-51.

36. Piedimonte G, Hegele RG, Auais A: Persistent airway inflammation after resolution of respiratory syncytial virus infection in rats. Pediatr Res 2004, 55:657-65.

37. Hu C, Wedde-Beer K, Auais A, Rodriguez MM, Piedimonte G: Nerve growth factor and nerve growth factor receptors in respiratory syncytial virus-infected lungs. Am J Physiol Lung Cell Mol Physiol 2002, 283:L494-502.

38. Carr MJ, Hunter DD, Jacoby DB, Undem BJ: Expression of tachykinins in nonnociceptive vagal afferent neurons during respiratory viral infection in guinea pigs. Am J Respir Crit Care Med 2002, 161:1985-90.

39. O'Connell F, Springall DR, Moradoghi-Haftvani A, Krausz T, Price D, Fuller RW, Polak JM, Pride NB: Abnormal intraepithelial airway nerves in persistent unexplained cough. Am J Respir Crit Care Med 1995, 1 52:2068-75

40. Birring SS, Brightling DE, Symon FA, Barlow SG, Wardlaw AJ, Pavord ID: Idiopathic chronic cough: association with organ specific autoimmune disease and bronchoalveolar lymphocytosis. Thorax 2003, 58: 1066-70.

4I. Mund E, Christensson B, Gronneberg R, Larsson K: Noneosinophilic CD4 lymphocytic airway inflammation in menopausal women with chronic dry cough. Chest 2005, I 27: |7| |4-172|

42. Fujimura M, Sakamoto S, Kamio Y, Matsuda T: Sex difference in the inhaled tartaric acid cough threshold in non-atopic healthy subjects. Thorax 1990, 45(8):633-4

43. Dicpinigaitis $P V$, Rauf $K$ : The influence of gender on cough reflex sensitivity. Chest 1998, I 13:1319-21.

44. Kastelik JA, Thompson RH, Aziz I, Ojoo JC, Redington AE, Morice $\mathrm{AH}$ : Sex-related differences in cough reflex sensitivity in patients with chronic cough. Am J Respir Crit Care Med 2002, 166(7):961-4.

45. Chang AB, Phelan PD, Sawyer SM, Del Brocco S, Robertson CF: Cough sensitivity in children with asthma, recurrent cough and cystic fibrosis. Arch Dis Child 1997, 77(4):331-4.

46. Prudon B, Birring SS, Vara DD, Hall AP, Thompson JP, Thompson JP, Pavord ID: Cough and glottic-stop reflex sensitivity in health and disease. Chest 2005, 127:550-7.

47. Ebihara T, Sekizawa K, Ohtui T, Nakzawa H, Sasaki H: Angiotensinconverting enzyme inhibitor and danazol increase sensitivity of cough reflex in female guinea pigs. Am J Respir Crit Care Med 1996, I53:812-9.
Publish with Biomed Central and every scientist can read your work free of charge

"BioMed Central will be the most significant development for disseminating the results of biomedical research in our lifetime. "

Sir Paul Nurse, Cancer Research UK

Your research papers will be:

- available free of charge to the entire biomedical community

- peer reviewed and published immediately upon acceptance

- cited in PubMed and archived on PubMed Central

- yours - you keep the copyright 